\title{
Potential socio-economic consequences of mine closure
}

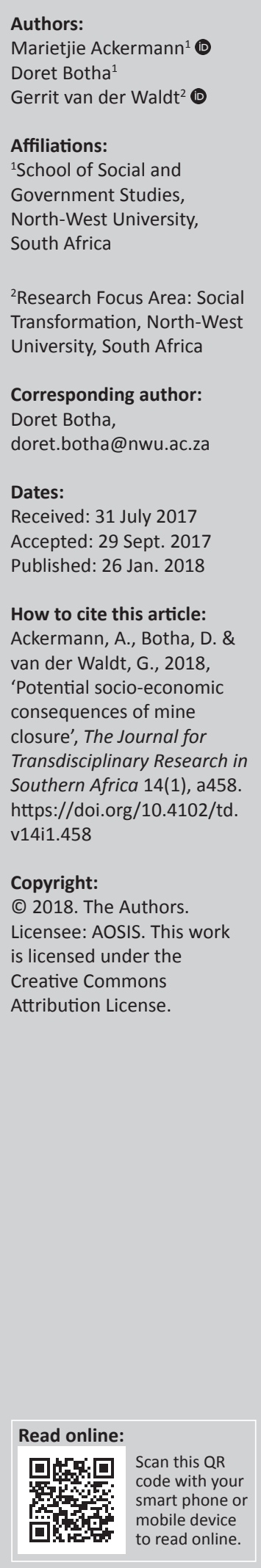

Background: Mine closures generally reveal negligence on the part of mining houses, not only in terms of the environment, but also the surrounding mining communities.

Aim: This article reflects on the findings of research into the socio-economic consequences of mine closure. The research specifically explored how mineworkers' dependency on their employment at a mine affects their ability to sustain their livelihood.

Setting: The research was conducted at the Orkney Mine and the Grootvlei Mine (Springs).

Methods: The research was conducted within a naturalistic domain, guided by a relativist orientation, a constructivist ontology and an interpretivist epistemology. Data were collected by means of document analysis, semi-structured interviews, focus group discussion and unstructured observation.

Results: From the research findings, it is evident that mine closures, in general, have a devastating effect on the surrounding mining communities as well as on the employees. Mine closures in the case studies gradually depleted the mining communities' livelihood assets and resulted in the collapse of their coping strategies and livelihood outcomes. It generally affected the communities' nutrition, health, education, food security, water, shelter, levels of community participation and personal safety.

Conclusion: If not managed efficiently and effectively, mine closures may pose significant challenges to the mining industry, government, the environment, national and local economic prosperity and communities in the peripheral areas of mines. This truly amplifies that mine closure, whether temporary or permanent, is an issue that needs to be addressed with responsibility towards all stakeholders, including the mining community and the labour force.

\section{Introduction}

South Africa is a resource-rich geographical area and provides many opportunities for mining houses to take on mining operations. The one significant contribution by the mining industry to South Africa is the employment opportunities it provides. In 2015, the mining industry contributed R286 billion towards the South African gross domestic product, directly employed 457698 individuals and indirectly supported roughly 4.5 million people (Chamber of Mines of South Africa 2017:6). For this reason, mining communities are potentially adversely affected by mine closures (Jenkins \& Obara 2008:3; Limpitlaw 2004:1).

Globally, there are a significant number of mines on the brink of life cycle closure (Camargo 2014; Stacey et al. 2010b:379; World Bank 2010:3). The International Council on Mining and Metals (ICMM) defines mine closure as:

a process that extends over the life cycle of the mine, and results in the handing over of the mining site (to the government or to a legally appointed third party), when operations cease and infrastructure is removed and the site is limited to monitoring. (ICMM 2008:13)

A mine should close in line with the definition of the ICMM, as a result of its finite lifespan, extracting from non-renewable resources, yet this is not always the case (Baartjes \& Gounden 2011:2; Stacey et al. 2010b:379). Mining operations and specifically mine closures reveal general inattention on the part of mining houses to potential consequences not only for the environment, but also for the mining community (Digby 2016). Mining communities include directly affected mining communities, adjacent or in close proximity to a mine, and labour-sending areas, which include areas from which the majority of mineworkers both historically and current are or have been sourced (RSA 2017:5). Negligence can also be attributed to the competence of organs of state tasked with the enforcement of the closure requirements (Liefferink 2009:6; Olalde 2016). 
Government is the regulator of the mining industry and should act as responsible mechanism to serve the public's interest to ensure a safe and healthy environment (Swart 2003:489). Mine closures have generally left behind a legacy of polluted areas, abandoned mines and ghost towns.

If not managed efficiently and effectively, mine closures may pose significant challenges to the mining industry, government, the environment, national and local economic prosperity and communities in the peripheral areas of mines (Limpitlaw 2004:2; Oliveira 2016). Ineffective mine closures also impact adversely on future generations. Mine closures, in terms of Section 24 of the Constitution and the concept of sustainable development, should address not only intergenerational equity, but also intergenerational equity (Hoadley \& Limpitlaw 2008:850). This truly amplifies that mine closure, whether temporary or permanent, is an issue that needs to be addressed with responsibility towards all stakeholders, including the mining community and the labour force (Digby 2016; World Bank 2010:14).

\section{Purpose of the study}

In light of the foregoing introduction, the purpose of this article is fourfold. Firstly, it provides a contextualisation of mine closure in South Africa. Secondly, it aims to highlight the application of the Sustainable Livelihood Framework (SLF) and the CARE Household Livelihood Security Framework (CARE HLSF), as they assisted in assessing socioeconomic consequences, and, in particular, how the loss of people's assets as a result of mine closure increased the vulnerability of the mining communities. Thirdly, the article has the purpose to reveal the socio-economic consequences of the closure of two mines formerly owned by the liquidated Pamodzi Gold Ltd, namely the Orkney Mine and the Grootvlei Mine, as case studies. Fourthly, the authors make practical recommendations to limit and address the socioeconomic consequences of mine closures.

\section{Literature review}

\section{A contextualisation of mine closure}

According to Laurence (2006:285), 'for the past decade or more, the term "mine closure" has firmly entrenched itself into the lexicon of mine operators and regulators'. Laurence (2006:285) further contends that 'even "hard-nosed" or "old school" mining engineers have come to appreciate that this phase is just as important as the other stages of the mining cycle'. Unfortunately, mine closures have also become a contested and controversial matter with a number of unresolved issues that landed on the table of government (Van Eeden, Liefferink \& Du Rand 2009:52).

Mines are usually closed at the end of their life cycle because of depleted resources, but may also be closed for other reasons such as economic, geological or structural reasons (Laurence 2006:286). Some mines in South Africa closed because of a number of reasons, including liquidation and legislation, or natural occurrences such as landslides and earthquakes. Temporary closure may occur because of the need for necessary care and maintenance when the mine has ceased production for various technical, environmental, financial or labour-related reasons (Swart 2003:490). Unfortunately, the last stage of mining, which is mine closure, still lacks the interest or prestige surrounding the other phases (Laurence 2006:285). A closure plan must contain the information set out in Appendix 5 of the Environmental Impact Assessment Regulations (RSA 2014). A closure plan must be subjected to a public participation process of at least 30 days. The closure plan must address the requirements, as set out in the regulations, pertaining to the financial provision for the rehabilitation, closure and post-closure of prospecting, mining or production operations made in terms of the Act.

The global focus on sustainable development and the impact of the increased efforts to protect the environment in the last few decades have changed the way the mining industry approaches the issue of mine closure. Ideally, good practice of mine closure planning emphasises that planning for closure of mining operations should be done during the exploring phase, when the feasibility of the mine and the design and permits for mining are established (Stacey et al. 2010b:379). Mine closure planning should uphold the following principle with respect to the mining community: 'using, conserving and enhancing the mining communities' (Stacey et al. 2010a:9).

\section{Mine closure in South Africa}

In South Africa, most mines are 50 years and older. South African regulators had been considering mine closure strategies merely in the previous 15-20 years (Digby 2016, as cited in Oliveira 2016). However, formal mine closure had been required in the Mines and Works Act (27 of 1956) and agreed to, in practice, under the Fanie Botha Accord of 1976 (International Institute for Environment and Development 2002:9). Historically, a mine was closed simply by being boarded up and abandoned when an ore body was exhausted, or when production ceased (Limpitlaw 2004:1). According to Swart (2003:489), the early legislation focused on 'surface rehabilitation' and the mining companies followed a reactive approach in which they complied with the mere minimum requirements. The irresponsible mining practices of the first mining companies left long-term residual effects on the social, health and environmental well-being of communities residing in the vicinity of the mine (Swart 2003:489).

Today, South Africa has a comprehensive statutory and regulatory framework to guide mining operations in the country. The Constitution of the Republic of South Africa 1996 provides general guidelines for the mining industry with regard to its operational and closure activities. As far as the socio-economic environment is concerned, Section 24 of the Constitution stipulates that everyone has the right to 'an environment that is not harmful to their health or well-being' and 'to have the environment protected, for the benefit of present and future generations' (RSA 1996). 
The Minerals Act (50 of 1991) (RSA 1991), the Nuclear Energy Act (131 of 1993) (RSA1993), the National Environmental Management Act (107 of 1998) (RSA 1998a), the National Water Act (36 of 1998) (RSA 1998b) and the National Nuclear Regulator Act (47 of 1999) (RSA 1999) further provide particular controlling measures for the mining sector. Furthermore, the Minerals and Petroleum Resources Development Act (28 of 2002) (MPRDA) initiated the required submission of a social and labour plan in order to obtain a mining licence (DMR 2010). The Mining Charter of 2004 (RSA 2004) and the Amended Mining Charter of 2010 (RSA 2010) also focused on the socio-economic aspects of mining and had a significant impact on the mining industry concerning maintaining sustainable development principles (Swart 2003:491, 492). Section 43 of the MPRDA provides for the issuing of a closure certificate by the Minister of Minerals and Resources and the transfer of closure liabilities to a competent person (RSA 2002). The following recent legislation was also introduced to further provide controlling measures for the mining industry: the Environmental Impact Assessment Regulations of 2014 (RSA 2014) and the National Environmental Management Act (107 of 1998) regulations pertaining to the financial provision for prospecting, exploration, mining or production operations (Warburton Attorneys 2016).

There is evidence of a growing ethical consciousness, a corporate social responsibility disposition in the mining industry. Mine owners are required by law to leave behind decommissioned infrastructure and sustainable economic arrangements that do not hamper opportunities for communities to function once a mine is closed (Stacey et al. 2010a:6).

\section{The Sustainable Livelihood Framework and the CARE Household Livelihood Security Framework}

The SLF and the CARE HLSF are instruments or tools that can be used to pinpoint, understand and analyse the main factors that affect the livelihood of poor people. As such, both frameworks were utilised for the purposes of this study.

\section{The Sustainable Livelihood Framework}

The SLF (see Figure 1), developed by the Department for International Development (DFID) in 1999, seeks to eliminate

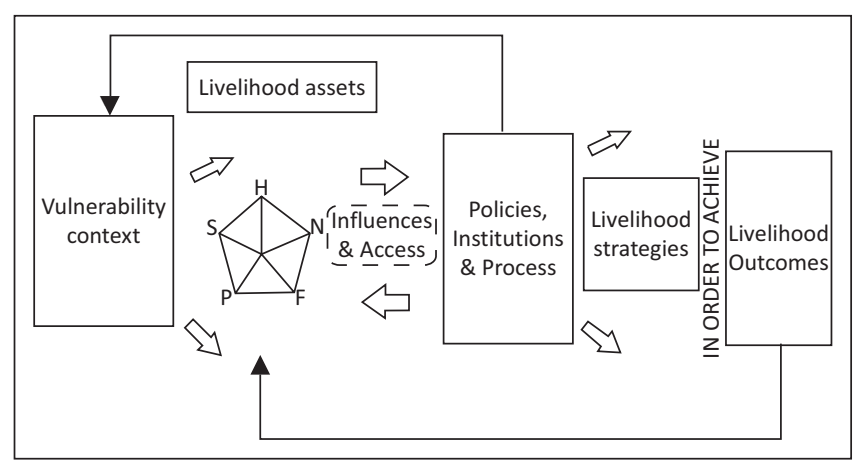

Source: DFID 1999

FIGURE 1: The Sustainable Livelihood Framework. poverty. It can be used as 'a tool or checklist to understand poverty in responding to poor people's views and their own understanding of poverty' (GLOPP 2008). The environment in which a community functions plays a pivotal role, as this is where the community negotiates its existence. Such an environment should provide sustainable livelihoods to the community in order for them to make a living. Chambers and Conway (1991, as cited in Knutsson 2006), define a livelihood as follows:

A livelihood comprises of the capabilities, assets and activities for a means of living. A livelihood is sustainable when it can cope and recover from stress and shocks, maintain or enhance its capabilities and assets, provide sustainable livelihoods for the next generation and which contributes net benefits to other livelihoods at local or global level. (p. 90)

The SLF enables agencies to identify stresses and shocks that increase the vulnerability of a community or entry points towards strengthening a community's capacity and resilience (Twigg \& Bottomley 2011:2).

The SLF includes the following components: the vulnerability context, livelihood assets, transforming structures and processes and livelihood strategies and outcomes (DFID 1999; GLOPP 2008:3).

The vulnerability context refers to the external environment of a community where stresses, shocks, trends and seasonality have a direct effect on the livelihood assets of a community. This causes a chain reaction, affecting people's livelihood strategies and outcomes. A negative input has an adverse effect on the assets, outcomes and strategies of the affected community.

Each community has different quantities and forms of livelihood assets available to them. To achieve positive livelihood outcomes, people require a range of assets. 'No single category of assets on its own is sufficient to yield all the many and varied livelihood outcomes that people seek' (DFID 1999). Livelihood assets are present in the internal environment of a community as well as in the external environment. These assets are listed as different forms of capital (DFID 1999):

- Human capital refers to skills, knowledge, health and energy.

- Social capital refers to networks, groups, institutions and family relations.

- Physical capital includes infrastructure, technology and equipment.

- Financial capital refers to savings, credit, pension fund and medical aid.

- Natural capital refers to natural resources, such as gold ore and water.

Transforming structures and processes refer to policies, institutions, organisations and other structures in which a certain community operates and that could affect the community's livelihood assets, strategies and outcomes positively or negatively. 
Livelihood assets determine both the livelihood strategies a community adopts and the livelihood outcomes a community achieves. Livelihood strategies refer to the goals the community is seeking for themselves regarding their livelihood and comprise a range and combination of activities and choices that people make or undertake to achieve these goals.

Livelihood outcomes refer to the 'achievements or outputs of livelihood strategies, such as more income, increased wellbeing, reduced vulnerability, improved food security and a more sustainable use of natural resources' (GLOPP 2008:4). If people or households have better access to assets, their ability to influence structures and processes will increase so that these become more responsive to their needs (Carney 2000, as cited in GLOPP 2008:4).

\section{The CARE Household Livelihood Security Framework}

The CARE HLSF emphasises the dynamic interrelationships between different aspects of the framework and also includes other approaches. CARE distinguishes between assets, capabilities and activities, rather than looking at using the 'five capitals' approach to assets (Anon s.a.:7). The CARE HLSF (see Figure 2) provides the opportunity to analyse the level of basic livelihood of a family and its coping mechanisms in the absence of such livelihood. The analysis of household security is determined by the interactions between assets, the household and the processing of these assets, as well as related activities of production, income and consumption. The framework explains the environment that should provide resources for the actions of production, income and consumption, which are represented by the collective term 'livelihood strategies'. These activities, or the absence or inability of a household to participate in them, would constitute the level of security or vulnerability that households face (Frankenberger, Drinkwater \& Maxwell 2000:1; Frankenberger et al. 2002:3).

The main components of the CARE HLSF are the household, the assets and the livelihood strategy and outcomes (Frankenberger et al. 2000, 2002).

The household is the most important and most affected by livelihood strategies and responds and reacts to internal and external factors in the environment, which is represented in the shocks and stresses box. In order for the household not to be vulnerable, it has to have assets and resources. Access to resources indicates that a household is resilient; hence, inability to access resources indicates vulnerability (Wisner, Gaillard \& Kelman 2012:27).

The assets box represents a variety of procurement strategies for food and cash. Assets refer to natural, human, social and economic capital and represent the degree of vulnerability of a community. The assets box explains the interaction of the

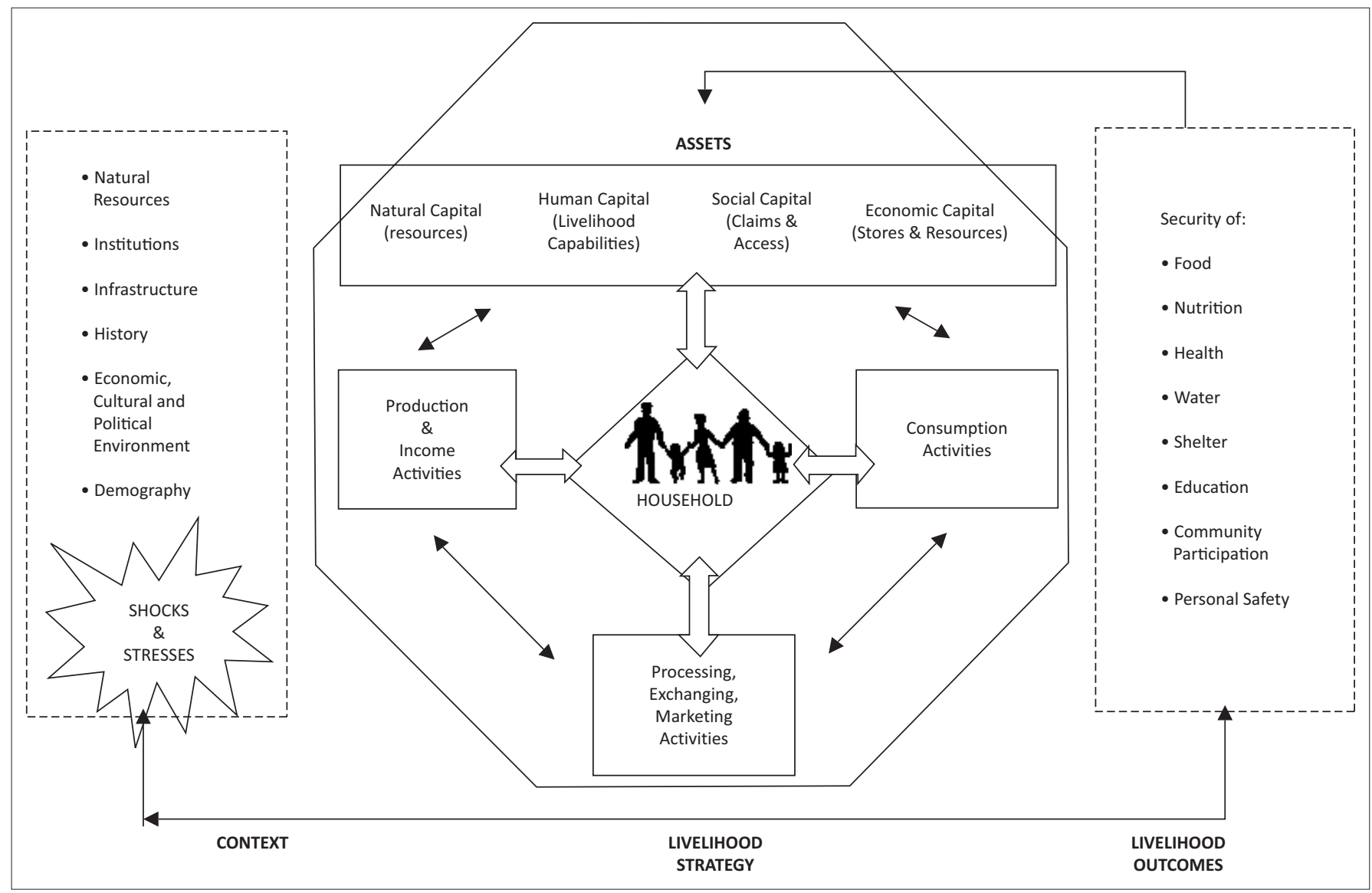

Source: Swift (1989), as cited in Frankenberger et al. 2000:5

FIGURE 2: The CARE Household Livelihood Security Framework. 
household to access resources that are provided in the external environment. The level of interaction is determined by the quality or quantity and value of assets available to the household (Krantz 2001:15).

Livelihood outcomes are positive when households have access to livelihoods, as well as security through access to food, water, shelter, education and community participation. Household livelihood security would imply that the inhabitants are able to acquire, protect, develop, utilise, exchange and benefit from assets and resources. Livelihood outcomes are hampered and diminished when a household cannot withstand shocks or meet contingencies that negatively affect assets and access to livelihood strategies (Frankenberger et al. 2000).

\section{Research methodology}

This study employed a qualitative research design. Qualitative research aims to capture reality through intense interaction, allows entry to subjective social constructions of people and offers 'thick' descriptions (Sarantakos 2013:45). The research was conducted within a naturalistic and interpretive domain, guided by a relativist orientation, a constructivist ontology and an interpretivist epistemology (cf. Sarantakos 2013:36).

\section{Research setting}

This research investigated the closure of two mines, namely the Orkney Mine and the Grootvlei Mine. The mines were purposively selected, as they were suddenly closed, without prior warning, mainly because of the liquidation of the mining companies.

In April 2009, Aurora Empowerment Systems negotiated to take over the ownership of the Grootvlei Mine (Springs), the Orkney Mine and the President Steyn Mine (Welkom), after the previous owners, Pamodzi Gold Ltd, were liquidated (Deep SA 2006:1). The takeover process was finalised in October 2009. The liquidation of Pamodzi Gold Ltd was unexpected, as this was an established, prospering black economic empowerment company, which was active in one of the richest gold-producing areas in the world, Orkney. The expectation was that by 2010, Pamodzi Gold Ltd would increase its output of gold to 1 million ounces per annum. Instead, from early 2009, Pamodzi Gold Ltd struggled to remunerate all of its workers (Stuit 2009; Van der Walt 2009:1). The following conditions arose at the two mines, Orkney and Grootvlei, after the liquidation of Pamodzi Gold Ltd:

- Since February 2009, only certain shafts were in operation and mineworkers experienced problems receiving their salaries. During April 2009, the mine was closed and workers, already struggling financially, were sent home without salary (Van der Walt 2009:3).

- During the period April 2009-October 2009, the mineworkers required emergency food aid. The welfare organisation Helping Hand (affiliated and partially funded by the labour union solidarity) provided food parcels to the unemployed mineworkers (T. Esterhuizen, personal interview, 25 March 2011). Schools in Orkney and Springs launched projects to feed the children, and parents began collecting funds to support the mineworkers and their children (Van der Walt 2009:1).

- In October 2009, the liquidation of Pamodzi Gold Ltd was finalised and the Orkney and Grootvlei mines were handed over to Aurora Empowerment Systems Ltd, which agreed to buy the liquidated mines from Pamodzi Gold Ltd (Williams 2009:7). In December 2009, the President Steyn Mine was bought by the Harmony Gold Group (Competition Tribunal 2009:1). The mineworkers thought that their situation was restored. Six shafts at the Orkney Mine and seven shafts at the Grootvlei Mine were reopened, raising the hope that the situation in the communities surrounding these mines would change (Aurora 2010; Williams 2009:7). The new owners began to pay partial salaries from December 2009 (Van Rensburg 2012).

- The situation soon changed and the crisis (as described above under the previous owners, Pamodzi Gold Ltd) repeated itself in 2010 (Van Rensburg 2012). The newly appointed managers of the Grootvlei and Orkney mines failed to pay employees' full salaries from April 2010. The mining activities ceased, except for a few miners overseeing the 'care and maintenance' of the Orkney and Grootvlei mines (Tempelhoff 2010a:12). These care and maintenance activities included basic maintenance of the mining equipment and shafts, as well as the daily pumping out of mine water to prevent the shafts and the surrounding areas from flooding. These workers were not remunerated in spite of working their normal shifts and beyond to keep the mines safe and to prevent the mine and the surrounding environment from being flooded with toxic mine water (Oberholzer 2010:38).

- Early in 2011, all the shafts at the Grootvlei Mine were finally closed down because of the following factors: safety risks of working with poorly maintained mining equipment, the continued non-payment of workers (after promises of pending remuneration) and the cutting off of the electricity supply to the mines because of unpaid Eskom accounts by Aurora (G. du Plessis, personal interview, 05 August 2011; Joubert 2011:2).

The issues surrounding these mines received extensive media attention. These issues included the non-payment of the Aurora mineworkers and the threat of a devastating environmental crisis posed by the mine water if the daily pumping of 108000 mega litres of water from the shafts would cease (Oberholzer 2010:38). The closing of the Orkney and Grootvlei mines affected an estimated 5300 mineworkers (with dependents) who lost their income (G. Esterhuizen, personal interview, 26 March 2011). As a result, the mineworkers and their dependents were living in dire circumstances and needed humanitarian assistance. Shafts at both mines were also flooded and ransacked, which caused permanent damage. The sudden closure of these mines left the surrounding communities in a state of crisis (A. Klopper, personal interview, 
08 August 2011). This study focused on the period under the new management, Aurora Empowerment Systems Ltd.

\section{Data collection and sampling}

Data were collected by means of document analyses, semistructured interviews, a focus group discussion and unstructured observations. The non-governmental organisation (NGO) Helping Hand assisted with the research and also formally sponsored it.

The document study included newspaper articles and Internet publications from the mining industry and government on the mine closures.

Semi-structured interviews are used to form a detailed picture of the participant's beliefs about, or perceptions or accounts of, a particular topic (Greeff 2005:296). Semi-structured interviews were employed to collect data from the mineworkers and their relatives in the surrounding mining communities (Orkney and Springs), business owners or managers in the two mining towns, the role players who assisted with the Helping Hand projects and members of the labour unions who were involved, directly or indirectly, with the plight of the mineworkers and the loss of their employment. The participants were purposively selected from a database provided by Helping Hand. Written field notes were also taken and interviews were recorded with the permission of the participants. The information gathered from the semi-structured interviews provided insight into the detrimental effects that the experience of the mine closure had on the participants.

Focus group discussions create a process of sharing and comparing information and experiences and produce large amounts of concentrated information (Greeff 2005:301). One focus group discussion was held with the mineworkers at the Orkney Mine who were living on site to gather information on the immediate needs their families experienced after the mine closure as well as to determine the effects on their livelihood and family life.

The two sites in Orkney and Springs, the Aurora-Orkney Mine and the Grootvlei Mine, were visited to gain insight into the circumstances of affected mining communities. The observation confirmed the magnitude of the damage on and to the mining site and correlated significantly with the data obtained from the interviews, document analysis, focus group discussion and literature survey.

The following ethical considerations were considered while collecting the data: voluntary participation, informed consent, privacy, anonymity and confidentiality, as recommended by Babbie and Mouton (2011:520).

\section{Data analysis}

The data were analysed by means of coding (thematic analysis). This process involves the sorting of data according to themes and phrases that the participants repeated (Oplatka 2001). The SLF and the CARE HLF were used to identify themes and categories from the data collected. The data collected were verified by means of source, method and data triangulation, which is regarded as one of the best ways to enhance the validity and reliability of qualitative research findings (Babbie \& Mouton 2011:275).

\section{Empirical findings}

By scrutinising the data, three main categories (livelihood assets, livelihood strategies and livelihood outcomes) with supporting themes and sub-themes were developed (see Table 1). The themes were identified according to variables that indicate an increase or decrease in the vulnerability of a community or household, unique to each category.

\section{Category A: Livelihood assets of the two mining communities}

Category A: Livelihood assets consist of five main themes: human capital, natural capital, financial capital, social capital and physical capital.

\section{Human capital}

Four sub-themes were derived from the theme human capital: skills, knowledge, health and energy. The mineworkers' skills were restricted to the mining industry only. When the mine closed, most of these workers were unable to find work; they could not afford travelling expenses to attend a job interview or they lacked the skills and abilities required to work outside the mining industry. Approximately 1000 mineworkers stayed on at the hostels of the mine, with no food and clean water (Tempelhoff 2010a:19). In general, there was a feeling of hopelessness and despair among the mineworkers who did not find employment and some completely gave up on hope to find employment.

TABLE 1: Categories and main themes used to analyse the data collected

\begin{tabular}{ll}
\hline Category & Theme \\
\hline A: Livelihood assets & Human capital \\
(different forms of capital) & Natural capital \\
& Financial capital \\
& Social capital \\
& Physical capital \\
B: Livelihood strategies & Consumption activities \\
(activities of a household in its & Production and income activities \\
socio-economic environment) & Processing, exchange and marketing activities \\
& Nutrition \\
C: Livelihood outcomes (results \\
from activities performed in the \\
context of livelihood strategies)
\end{tabular}




\section{Natural capital}

Data collected from the document study revealed that criminal charges were brought against the mining company Aurora for discharging inadequately treated acid mine water into the wetlands surrounding the Springs area (Tempelhoff 2010b:9). A scientific report published by Van Vuuren (2013) confirms that the Blesbok Spruit is contaminated by acid mine drainage. Data gathered from the semi-structured interviews revealed that the vegetable gardens of the miners residing at the hostels, at the Orkney and Springs mines, were watered from untreated mine water.

\section{Financial capital}

The main effect of the mine closure at the Orkney and Grootvlei mines was the mass loss of employment. At first, Aurora promised that they would not lay off any of the workers (Van Rensburg 2012:7). However, within a few months after the takeover from the previous owners, the workers were unemployed. As a result, most of them lost their medical aid, unemployment insurance fund (UIF) and pension benefits, some after working 25 years for the mining industry (PMG 2013). It is reported that even though the money for their pension and medical aids was subtracted from their salaries, the mining companies did not pay over their money to the respective funds (Tempelhoff 2010b:12). Payments were also not made to the UIF. Furthermore, value-added tax was never paid on any of the transactions made by Aurora (PMG 2013). The mine owners were accused by the media of running the two mines on a Ponzi scheme. This practice involves making payments on the grounds of promises of money based on forthcoming income and funding, which was never realised in the case of Aurora (Pauw 2012).

\section{Social capital}

Deterioration of networks and social groups was reported. Mineworkers had to change their lifestyles to adapt to their newly acquired statuses of low income or no income. Some of the mineworkers who were part of the care and maintenance team had to sleep at the mine. They actually had no money for transport to take them home, as they received no salary for 4 months (Tempelhoff 2010a:10). The mine closure negatively affected 40000 people. The findings showed that mineworkers who were laid off had an estimated 4-10 dependents (G. du Plessis, personal interview, 05 August 2011). The number of workers who suddenly became unemployed at the two mines was 5300 , according to calculations by the media, and according to estimates of Helping Hand, about 40000 mineworkers and their dependents were affected (Deikema 2010a).

A significant number of participants and many reports indicated an overall presence of depression and feelings of hopelessness among the people in the communities concerned. Instances of substance abuse, domestic violence and divorce escalated. A number of suicides, suicide attempts and attempted family murders were reported after the mine closures (Deikema 2010b; Oberholzer 2010:38).

\section{Physical capital}

Equipment and tools: The mines that provided employment to 5300 workers were stripped of equipment, which reportedly was sold as scrap metal. Furthermore, the flooding of the mining shafts worsened the damage to the mines, and will cost millions to repair before mining operations could take place again (Du Venage 2011). When approached on this issue, the owner reacted: 'I do not owe you any explanation' (De Lange 2011:2).

Technology: The companies that supported the mines with basic services such as electronics, electricity and security were not paid and their services were duly terminated. Some of the smaller businesses that benefitted from the mining operations and workers' salaries were closed down or went bankrupt after the mines closed. Electricity was cut in 2010 because of the non-payment of bills to Eskom and because the amounts exceeded the mine owners' ability to pay (G. du Plessis, personal interview, 05 August 2011).

Infrastructure: The buildings in which the mine offices were situated were left empty and were not maintained. Electricity at the mines and at the homes of mineworkers was cut off because of lack of payment to Eskom and the local municipalities (Deikema 2010a). The entrance to the gate and the roads were not maintained and showed signs of damage. The pipes were rusting because of lack of maintenance and caused a safety risk to the workers who were part of the care and maintenance operations (Tempelhoff 2010a:9). Workers of the care and maintenance unit complained that the lights on their safety helmets were faulty and miners had to rotate the helmets among them to have light when working underground. The following comment was made in this regard:

The mine was destroyed, the environment endangered and equipment for employment was removed - Interview at Helping Hand, and government publication (PMG 2013)

\section{Category B: Livelihood strategies of the two mining communities}

Three sub-themes were derived from the theme livelihood strategies: production and income activities, consumption activities and processing, exchange and marketing activities. The effect of the mine closure on the livelihood strategies of the mining communities under investigation is revealed below.

\section{Production and income activities}

Mineworkers reported that they arrived at closed gates in April 2010. Their main activity to provide income to their families was ended abruptly, leaving them in despair. The damage to the mining sites also destroyed the possibility that the mines will be in operation any time soon (De Lange 2011).

\section{Consumption activities}

The lack of income and loss of cash flow excluded the mineworkers and their relatives from normal activities to which they had access prior to the mine closure. These include being 
able to partake in social activities such as eating at restaurants and going to places of entertainment provided by the city and municipality. Interviews with the business owners during the observation of the mining site confirmed a severe drop in the mining communities' ability to partake in these activities. The families affected by the mine closure did not even have the finances to buy groceries and the basic personal items that they needed (Tempelhoff 2010a:9). The workers and their families needed food parcels because of the non-payment of salaries from April 2010 to October 2010 (Deikema 2010a, 2010b).

\section{Processing, exchange and marketing activities}

The mining communities under investigation depended on the mine as their main source of income. The workers' salaries provided them with the opportunity to also partake in the local market. When the mines closed, they lost their ability to participate in this aspect of their livelihood strategies. Production and exchange opportunities were not a main activity, even though it was reported that the mineworkers living at the hostels maintained vegetable gardens to sustain themselves and their families. The mine closure affected the mineworkers living in the mining town differently than those who remained at the hostels. A newspaper reported: 'More than 1000 mineworkers are waiting at the hostels, with no clean running water, and without food' (Tempelhoff 2010a:9). No data were collected from the miners living in town that reflected any activities of production or exchange of livelihoods, other than the salaries that they received for working on the two mines mentioned in this study.

\section{Category C: Livelihood outcomes of the two mining communities}

The following sub-themes were derived from the theme livelihood outcomes: nutrition, health, education, food security, water, shelter, community participation and personal safety.

\section{Nutrition}

Nutritional status is often considered one of the best outcome indicators for overall livelihood security. The inability of the households to provide nutrition for their children was evident from the following responses:

The mineworkers are living in terrible conditions at the hostels for months; there is no food, water or electricity. (PMG 2013)

My neighbour died, I think he was depressed, there was nothing to eat. Another neighbour died of hunger. (Orkney Mine, Female mineworker living in hostel after the mine closed)

I fell pregnant. I was under stress all the time, not having enough to eat during my pregnancy. My baby was declared dead after it was born. (Springs, Mineworker's life partner, Female)

Malnutrition was reported by all the participants. This condition resulted in miscarriages and bouts of depression among children and adults. Children felt ashamed of their situation at home. As a result, suicide attempts and suicidal behaviour were reported in the mining communities, the media and the semi-structured interviews. Proper nutrition is crucial as an expression of general health and well-being of a community, of which regular access to food is only one aspect. Nutrition is also very important in supporting psychological behaviour (WHO 2013).

\section{Health}

Conditions of health-threatening situations were reported from all the sources of collected data, including deterioration of the physical health as well as the psychological health of the mining communities. These conditions manifested in tendencies of diabetes, heart conditions, miscarriages, depression, increased mental health issues, substance abuse, suicides and, for children, learning difficulties that impacted negatively on their school performance. The following responses from the interviews corroborate this situation at the mines:

There was an increase of substance abuse and domestic violence after the mine closure. (Interview at Helping Hand, Media Spokesperson, Female)

Divorces occurred; schools had to provide food for the children who arrived at school hungry, people moved in together, ... two to three families in one home. (Deikema 2010b)

\section{Education}

Children experienced learning problems and were not motivated to perform well at school. Children had to cope with their households' new financial position in which parents were not able to provide new school clothes; they had to wear secondhand clothes. It was reported that one child was so embarrassed that he attempted suicide. Children were taken out of school because of non-payment of school fees (Deikema 2010b). Some children also did not have access to their year-end academic results because their parents owed money to the school. Children arrived hungry at school and as a result feeding schemes were launched at the schools (Van der Walt 2009:1).

\section{Food security}

The two communities had no food security during this event. The community lost their access to food because of the nonpayment of their salaries for a prolonged period. Food parcels were distributed to the miners and their families on a regular basis between April and December 2010 (Deikema 2010a, 2010b). Food parcels provide basic foods and do not always make provision for the needs of the family for proper nutrition to ensure psychological health as well as growth and development in children (WHO 2013).

Food security is an extremely important aspect of the CARE HLSF. The need for food is almost in every case the first sign of a community's vulnerability and of a condition of poverty (Frankenberger et al. 2002). This condition becomes apparent from the responses below:

The mineworkers received half their salaries at the end of December 2009, and this continued into March 2010, then in April, the mine closed and no salaries were paid. (Interview at Helping Hand, Labour networking consultant, Female )

I ask myself if life is still worth living if you have lost everything and have nowhere to go, and no food to eat. (Orkney Mine, Male mineworker) 


\section{Water}

Polluted mine water, untreated by the mine owners, was not only posing a health threat to the community exposed to the water, but was also threatening to flood the whole municipal area in the long run. The impact on the mining community was not only on conditions of personal health, but also on the entire external environment on which the community members depend for their existence. The following comments describe the situation experienced by mineworkers:

108000 mega liters must be pumped out of the mines daily to prevent the flooding of the shafts of the mines in the vicinity of Grootvlei mine, and of Nigel. (Oberholzer 2010:89)

The mine shafts do not have fences around them, the mine dumps are not treated and it holds risks to the mining community living in that area. The polluted mine water [is] used to irrigate the vegetable gardens where the mineworkers live. (Interview at Helping Hand, Environment spokesperson, Male)

\section{Shelter}

The mineworkers received partial salaries for 3 months and thereafter from April 2010 no remuneration at all. The partial payment and non-payment of their salaries influenced their ability to keep up the payments on their housing. Mineworkers who did not live in the mine hostels lost their homes and were forced to find less expensive accommodation. Some families moved in together and two to three households shared expenses. Some families had to leave town and went to live in areas that provided arrangements for informal settlements. Many hostel residents had nowhere to go and stayed on in the hostels, which were not supplied with running water and electricity anymore.

\section{Community participation}

Before the mine closure, some of the families of the mining communities had access to higher middle-class lifestyles. They could eat out regularly, some families possessed more than one vehicle and they participated in normal activities in their local municipalities. Mineworkers could plan for their children's education, and some supported their children in further studies after school. After the mine closure, these families had to go on foot when they needed something in town, and in some cases, they found themselves in situations where they had to beg for food from local businesses and churches. The parents also could not pay the fees for their children to participate in tertiary education anymore.

\section{Personal safety}

When the mines were in the 'care and maintenance phase', the few workers who did go down the shafts had to face the danger of faulty tools, unsafe shafts and defective mining equipment.

\section{Discussion and lessons learnt}

The mine closure experienced by the two mining communities was referred to as a human tragedy. This tragedy caused human suffering because of negligence and the inability to manage the mines and run the mining operations (Joubert
2011:2; Tempelhoff 2011:8). It resulted in the collapse of the mining communities' livelihood assets, livelihood strategies and livelihood outcomes.

The mineworkers did not immediately leave the mining sites to find alternative employment. Some mineworkers still arrived for work each day; they worked in the shafts, performing 'care and maintenance' tasks and preventing the mines from flooding without receiving compensation. Others stayed on in the hostels. This delay in their ability to generate salaries to meet the needs of their dependents negatively affected their livelihood outcomes. Workers stayed on after the closure for the following reasons: they regarded the mine closure as a temporary situation, they trusted the new owners and they were loyal to the mines. The necessary steps to protect the total deterioration of their livelihood were delayed because of the expectation that the situation would return to normal in a matter of weeks. By the time the mineworkers and the labour unions realised that the situation was entering into a longer term than expected, and that the workers were not going to be paid, the loss of their assets and livelihood was beyond recovery. Most mineworkers who did not find other employment had to make radical lifestyle adjustments. Such adjustments included moving to informal settlements, sharing homes with two or three other families and sharing scarce food resources among each other to avoid starvation. Most mineworkers needed humanitarian assistance.

The only positive input bringing relief to the suffering communities came from the labour unions and the NGOs who assisted the mining communities with food parcels and tended to other needs that arose from the mine closure. Helping Hand played a pivotal role in avoiding a crisis when the mines closed. Their immediate and timely involvement helped mitigate the effect the mine closure had on the socioeconomic well-being of the mineworkers and their dependents. Helping Hand also initiated legal investigations, which led to court cases in which the mineworkers' case was presented. Gift of the Givers supported the mineworkers with food in Orkney for several months. The efforts of Helping Hand to increase awareness of the situation resulted in widespread media attention and fundraising projects. Eventually, the case was presented to parliament on numerous occasions (G. du Plessis, personal interview, 05 August 2011).

It was evident from the findings that the mining communities were already vulnerable, even before the mines closed, because of their unsustainable livelihood. They depended on only one source of income, namely from the mines where they were employed. The mining communities were not secure in sustaining their livelihood assets. Their human capital, natural capital, financial capital, social capital and physical capital were affected. As indicated in the literature review, livelihood assets determine both the livelihood strategies a community adopts and the livelihood outcomes a community achieves and are affected by stresses and shocks in the environment (DFID 1999; GLOPP 2008:3). Therefore, 
the mine closure impacted negatively on the communities' livelihood strategies and livelihood outcomes. With regard to their livelihood strategies, the following were affected: their production and income activities, consumption activities and processing, exchange and marketing activities. In the SLF, these livelihood strategies are also referred to as the vulnerability context. Livelihood assets and resources are of utmost importance to protect a community from being vulnerable and to achieve positive livelihood outcomes (DFID 1999; GLOPP 2008:3; Wisner et al. 2012:27). The mine closure depleted the mining communities' livelihood assets and resulted in a total collapse of the workers and their families' livelihood assets and outcomes. It affected the communities' nutrition, health, education, food security, water, shelter, community participation and personal safety.

According to Christopolos (2012:547), a socio-economic disaster follows when vulnerability of livelihood deteriorates into total collapse. A socio-economic disaster does not only entail the loss of employment, but also implies a humanitarian crisis, in which a large number of people would be suffering because of a severe negative impact on their socio-economic well-being (Coppola 2007:26).

\section{Conclusion and recommendations}

From the research, it is evident that mine closures have a devastating effect on the surrounding mining communities as well as on the employees. It affects their livelihood assets, livelihood strategies and livelihood outcomes. Therefore, it is of utmost importance that mining companies and the relevant stakeholders participate in careful and thorough planning for mine closures. In light of the findings of the research, the following recommendations are made to mitigate the socio-economic consequences following an unexpected mine closure:

- Mining companies should develop a contingency plan to mitigate the potential socio-economic consequences of an unexpected mine closure. A contingency plan will assist in building resilience into the livelihood strategies of mineworkers and their dependents and it will create the ability for an organisation to respond and meet immediate needs for sustenance in a mining community after a mine closure.

- Mineworkers must be involved in planning for closures and in all other matters that involve them and the sustainability of their employment.

- Community participation should be promoted. Community members should be involved in all activities and planning to deal with an expected emergency. Community members must be able to voice their concerns and represent themselves and their marginalised groups on equal grounds with the local stakeholders (Twigg \& Bottomley 2011).

- Mine closure insurance, made available in monthly payments for a fixed period or as a lump-sum payment, would provide protection during the months when the workers are not remunerated. This measure could assist workers in the period of temporary closure of a mine or during the period of transition from one employer to another.

- Labour unions dealing with mineworkers should take the leading role to act as watchdogs on behalf of the mining industry. They must ensure that mine owners who employ their members uphold the principles of the social and labour plans proposed by the Mining Charter and the MPRDA. Mine owners are obliged to follow up on their commitment to develop the skills of mineworkers. Learning new skills would help mitigate the devastating effects a mine closure has on the mineworkers and their livelihood assets, strategies and outcomes.

- It is also recommended that the state prosecutes directors of mining companies who fail in their duty of care (the specific requirements for the duty of care are stipulated in Section 28 of the National Environmental Management Act (107 of 1998). The systemic non-enforcement by organs of state for non-compliance with the relevant laws and regulations, in particular mine closure, encourages delinquent behaviour with impunity.

\section{Acknowledgements}

This article is based on Mrs Marietjie Ackermann's dissertation, North-West University. The non-governmental organisation Helping Hand assisted with the research and also formally sponsored it.

\section{Competing interests}

The authors declare that they have no financial or personal relationships which may have inappropriately influenced them in writing this article.

\section{Authors' contributions}

M.A. conducted the literature review as well as the empirical research. D.B. acted as supervisor of the research project, assisted with the literature review and the empirical research and wrote up the article. G.v.d.W reviewed the article.

\section{References}

Anon, s.a., Introduction to the livelihoods framework, viewed 29 June 2017, from http://www.phuhlisani.com/oid\%5Cdownloads $\% 5$ CCh1.pdf

Aurora, 2010, Aurora empowerment systems, viewed 16 March 2011, from http:// www.auroraempowerment.com/news-pamodzi.html

Baartjes, N.L. \& Gounden, K.G., 2011, 'Causes of mine decline in South Africa', paper presented at the International Mine History Congress, Johannesburg, 15-18 August, viewed 27 May 2016, from http://www.imhc.co.za/assets/pdf/papers/ Declining\%20Mining\%20in\%20SA\%20Paper-Neale\%20Baartjies.pdf

Babbie, E. \& Mouton, J., 2011, The practice of social research, Oxford University Press, Cape Town.

Camargo, R., 2014, Holistic mine closure planning: Social, biophysical and financial, Iron Ore Brazil \& Anglo American, viewed 29 January 2016, from http://www. mineclosuresolutions.com/wp-content/uploads/2014/05/KEYNOTE-6-CamargoRicardo-Holistic-mine-closure-planning-approach-social-biophysical-and-financial.pdf

Chamber of Mines of South Africa, 2017, Mine SA 2016: Facts and figures, viewed 02 March 2017, from http://www.chamberofmines.org.za/industry-news/ publications/facts-and-figures

Christopolos, I., 2012, 'Food security and disaster', in B. Wisner, J.C. Gailard \& I. Keiman (eds.), The Routledge handbook of hazards and disaster risk reduction, pp. 543-552, Routledge, London.

Competition Tribunal, 2009, Harmony Gold Mining Company Ltd v Pamodzi Gold Free State (Pty) Ltd. Case nr: 71/LM/Oct09.

Coppola, D.P., 2007, Introduction to international disaster management, Elsevier, s.I. 
Deep SA, 2006, Pamodzi Gold Limited is the only JSE-listed gold mining company in South Africa to be owned and controlled by historically disadvantaged South Africans (HDSAS). A celebration of mining in South Africa, viewed 03 January 2011 from http://www.nelida.co.za/pdf/pamodzi.pdf

Deikema, R., 2010a, Solidariteit kondig reddingsplan vir voormalige Aurora werknemers aan, viewed 05 May 2013, from http://www.solidariteit-blog.co.za/ solidariteit-kondig-reddingsplan-vir-voormalige-werknemers-van-aurora-aan

Deikema, R., 2010b, Nood by Grootvlei myn skok, viewed 05 May 2013, from http:// www.solidariteit-blog.co.za/nood-by-grootvlei-en-orkney-myn-skok

De Lange, J., 2011, 'Grootvlei left in ruins', Miningmx, 19 June, viewed 15 November 2012 from http://www.miningmx.com/opinion.columnists/grootvlei-lef-in-ruins.htm

Department for International Development (DFID), 1999, Sustainable livelihoods, viewed 11 July 2011, from http://www.efls.ca/webresources/DFID_Sustainable livelihoods_guidance_sheet.pdf

Department of Mineral Resources (DMR), 2010, Revised social and labour plan guidelines, viewed 10 April 2016, from www.dmr.gov.za/guidelines-revised-socialand-labour-plans/.../119-how-to.html

Digby, C., 2016, Global challenges in mine closure, online video, viewed 01 May 2016, from http://www.miningweekly.com/article/mining-industry-resistant-to-mineclosure-and-rehabilitation-2016-05-27/rep_id:3650

Du Venage, G., 2011, Quotas spark ruin at mining company left with blood on its hands viewed 15 May 2013, from http://www.thenational.ae/business/industry-insights/ economics/quotas-spark-ruin-at-mining-company-left-with-blood-on-its-hands

Frankenberger, R.T., Drinkwater, M. \& Maxwell, D., 2000, Operationalizing household livelihood security: A holistic approach for addressing poverty and vulnerability, viewed 27 June 2016, from http://pqdl.care.org/Practice/HLS\%20-\%20 Operationalizing $\% 2$ HLS\% $20-020$ A $\% 20$ Holistic\%20Approach.pdf

Frankenberger, R.T., Luther, K., Becht, J. \& McCaston, M.K., 2002, Household livelihood security assessments: A toolkit for practitioners, Tango International and Care USA, viewed 27 June 2016, from http://www.chs.ubc.ca/archives/files/ Household-Livelihood-Assessment.pdf

Globalisation and Livelihood Options of People living in Poverty (GLOPP), 2008, DFID's sustainable livelihoods approach and its framework, viewed 27 June 2017, from sustainable livelihoods approach and its framework, vie
http://www.glopp.ch/B7/en/multimedia/B7_1_pdf2.pdf

Greeff, M., 2005, 'Information collection: Interviewing', in A. de Vos, H. Strydom, C.B. Fouché \& C.S.L. Delport (eds.), Research at grass roots, 3rd edn., pp. 286-314, Van Schaik, Pretoria.

Hoadley, E.M. \& Limpitlaw, D., 2008, Preparation for closure: Community engagement and readiness starting with exploration, viewed 26 September 2017, from https://www. researchgate.net/publication/242256553_Preparation_for_Closure_Community Engagement_and_Readiness_Starting_with_Exploration

International Council on Mining and Metals (ICMM), 2008, Planning for integrated mine closure, viewed 22 February 2016, from https://www.icmm.com/ document $/ 310$

International Institute for Environment and Development, 2002, Mining for the future. Appendix C: Abandoned mines, Working paper, viewed 26 Septembe 2017, from http://pubs.iied.org/pdfs/G00882.pdf

Jenkins, H. \& Obara, L., 2008, Corporate social responsibility (CSR) in the mining industry - The risk of dependency, viewed 22 February 2016, from http://www. crrconference.org/Previous_conferences/downloads/2006jenkinsobara.pdf

Joubert, J., 2011, 'Voorlegging in parlement: Pligsversuim lei tot Aurora-lyding', Rapport, 17 April, p. 2.

Knutsson, P., 2006, 'The sustainable livelihoods approach: A framework for knowledge integration assessment', Human Ecology Review 13(1), 90-99.

Krantz, L., 2001, The sustainable livelihood approach to poverty reduction: An introduction, viewed 29 June 2017, from http://www.sida.se/contentassets/ bd474c210163447c9a7963d77c64148a/the-sustainable-livelihood-approach-topoverty-reduction_2656.pdf

Laurence, D., 2006, Mine closure procedure, viewed 10 May 2010, from http://www. sciencedirect.com/science?_ob=MiamilmageURL\&_cid=271750\&_user $=745831 \&$ $\mathrm{pii}=$ S0959652605000399\&_check=y\&_origin=article\&_zone=toolbar\& coverDate=31-Dec-2006\&view $=$ c\&origin ContentFamily=serial\&wchp=dGLzVIt-zSkz $\& m d 5=e e 5 f 2 c 2 c 1 f 8 a 5 a 32214 b 95$ eedee018af/1-s2.0-S0959652605000399-main.pdf

Liefferink, M., 2009, Submissions to the Karoo Development Conference and Trade Fair Proposed Uranium Mining within the Beaufort West area, viewed 26 September 2017 from http://www.fse.org.za/Downloads/URANIUM\%20MINING\%20KAROO.pdf

Limpitlaw, D., 2004, Mine closure as a framework for sustainable development, paper presented at the Sustainable Development Practices on Mine Sites Conference, University of the Witwatersrand, Johannesburg, 8-10 March, viewed 23 July 2012, from http://www/csmi.co.za/l/papers/Mine_closure_as_framework_for SD_mar04.pdf

Oberholzer, C., 2010, 'Hedendaagse helde by Aurora', Solidariteit Tydskrif, 8 November, p. 6.

Olalde, M., 2016, SA's failed system of mine closure, viewed 26 September 2017, from https://www.iol.co.za/news/opinion/sas-failed-system-of-mine-closure-7117963

Oliveira, D., 2016, Mine closure, rehabilitation getting more attention from regulators, viewed 02 March 2017, from http://www.miningweekly.com/article/miningindustry-resistant-to-mine-closure-and-rehabilitation-2016-05-27

Oplatka, I., 2001, 'Building a typology of self-renewal: Reflection upon-life story research', The Qualitative Report 6(4), 1-20, viewed 13 June 2011, from http:// www.nova.edu/ssss/QR/QR6-4/oplatka.html

Parliamentary Monitoring Group (PMG), 2013, Updates on the Grootvlei and Orkney mines: Briefings by the Department of Labour, Provisional Liquidators \& NUM, viewed 26 March 2013, from http://www.pmg.org.za/report/20130326-updates-grootvleiand-orkney-mines-briefings-by-department-of-labour-provincial-liquidators-num
Pauw, J., 2012, 'Aurora "was run like a Ponzi scheme"', Fin 24, 25 March, viewed 25 July 2013, from http://www.fin24.com/Companies/Mining/Aurora-was-run-likea-Ponzi-scheme-20120325

Republic of South Africa (RSA), 1991, Minerals Act 50 of 1991, Government Printers, Pretoria.

Republic of South Africa (RSA), 1993, Nuclear Energy Act 131 of 1993, Government Printers, Pretoria.

Republic of South Africa (RSA), 1996, The Constitution of the Republic of South Africa, Government Printers, Pretoria.

Republic of South Africa (RSA), 1998a, National Environmental Management Act 107 of 1998, Government Printers, Pretoria.

Republic of South Africa (RSA), 1998b, The National Water Act 36 of 1998, Government Printers, Pretoria.

Republic of South Africa (RSA), 1999, The National Nuclear Regulator Act 47 of 1999, Government Printers, Cape Town.

Republic of South Africa (RSA), 2002, Mineral and Petroleum Resources Development (MPRDA) Act 28 of 2002, Government Printers, Pretoria.

Republic of South Africa (RSA), 2004, Broad-based socio-economic empowerment charter for the South African mining and minerals industry, Government Printers, Pretoria.

Republic of South Africa (RSA), 2010, Amendment of the broad-based socio-economic empowerment charter for the South African mining and minerals industry, viewed 20 May 2017, from http://www.dmr.gov.za/publications/summary/108-miningcharter-downloads/128-amended

Republic of South Africa (RSA), 2014, National Environmental Management Act 107 of 1998: Environmental impact assessment regulations, 2014, viewed 26 September 2017, from http://extwprlegs1.fao.org/docs/pdf/saf142066.pdf

Republic of South Africa (RSA), 2017, Broad-based black socio-economic empowerment charter for the South African mining and minerals industry, viewed 26 September 2017, from http://www.dmr.gov.za/gazetted-mining-charter-2016/summary/24mining-charter/8867-broad-based-black-socio-economic-empowerment-charterfor-the-south-african-mining-and-minerals-industry-2017.html

Sarantakos, S., 2013, Social research, 4th edn., Palgrave Macmillan, New York.

Stacey, J., Naudé. A., Hermanus, M. \& Frankel, P., 2010a, The economic aspects of mine closure and sustainable development: Literature overview of lessons for the socio-economic aspects of closure, Project 73835 of the Coaltech Research Association, viewed 20 May 2017, from http://www.coaltech.co.za/chamber\%20 databases $\% 5$ Ccoaltech\%5CCom_DocMan.nsf/0/13C0E50053B60B8788257AF40 03392EC/\$File/Coaltech\%20Mine\%20Closure\%20Report\%201\%202010.pdf

Stacey, J., Naudé. A., Hermanus, M. \& Frankel, P, 2010b, 'The socio-economic aspects of mine closure and sustainable development: Literature overview and lessons for the socio-economic aspects of closure - Report 1', The Journal of the Southern African Institute of Mining and Metallurgy 110, 379-394

Stuit, A., 2009, ' 400000 South Africans face famine by black gold mine closure', Digita Journal, viewed 01 December 2010, from http://www.digitaljournal.com/ article/270798

Swart, E., 2003, 'The South African legislative framework for mine closure', The Journal of the South African Institute of Mining and Metallurgy 103(8), 489-492.

Tempelhoff, E., 2010a, 'Betaal of ons skakel die pompe af', Beeld, 4 June, p. 12

Tempelhoff, E., 2010b, 'Pensioengeld van 2000 by bankrot myn in gedrang', Beeld, 19 March, p. 12.

Tempelhoff, E., 2011, 'Mynwater: Praat of ons doen stappe! Groepe stel ultimatum aan regering', Beeld, 27 January, p. 9.

Twigg, J. \& Bottomley, H., 2011, Making local partnerships work for disaster risk reduction, HPN Humanitarian Practice Network at ODI, viewed 05 June 2011, from http://www.odihpn.org/humanitarian-exchange-magazine/issue-50/makinghttp://www.odihpn.org/humanitarian-exchange-m
local-partnerships-work-for-disaster-risk-reduction

Van der Walt, N., 2009, 'Myners huis toe, geen geld. Planne vir noodfondse, skoolhulp aan die gang', Noordwes Beeld, 3 April, p. 1.

Van Eeden, E.S., Liefferink, M. \& Du Rand, J.F., 2009, 'Legal issues concerning mine closure and social responsibility on the West Rand', The Journal for Transdisciplinary Research in Southern Africa 5(1), 51-71.

Van Rensburg, D., 2012, 'Aurora se Pamodzi- plan kry vlerke of duik', Beeld, 31 March, p. 7.

Van Vuuren, L., 2013, Olifant's time to stand up for a river under siege, viewed 15 October 2013, from http://www.orf.co.za/PDF/Water $\% 20$ Wheel $\% 20$ May $\% 20$ 2013_Olifants $\% 20$ River.pdf

Warburton Attorneys, 2016, National Environmental Management Act 107 of 1998 : Regulations pertaining to the financial provision for prospecting, exploration, mining or production operations, viewed 26 September 2017, from http://www.

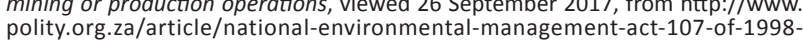
polity.org.za/article/national-environmental-management-act-107-of-1998-
regulations-pertaining-to-the-financial-provision-for-prospecting-explorationregulations-pertaining-to-the-financial-provis
mining-or-production-operations-2015-11-26

Williams, F., 2009, 'Pamodzi gold finaal in hof gelikwideer', Sake 24, 7 October, p. 7.

Wisner, B., Gaillard, J.C. \& Kelman, I., 2012, 'Framing disaster: Theories and stories seeking to understand hazards, vulnerability and risk', in B. Wisner, J.C. Gailard \& I. Kelman (eds.), The Routledge handbook of hazards and disaster risk reduction, pp. 18-33, Routledge, London.

World Bank, 2010, Towards sustainable decommissioning and closure of oil fields and mines: A toolkit to assist government agencies, viewed 16 July 2013, from http:// siteresources.worldbank.org/EXTOGMC/Resources/336929-1258667423902/ decommission_toolkit3_full.pdf

World Health Organization (WHO), 2013, Mental health, viewed 16 July 2013, from http://www.who.int/topics/mental_health/en/ 